\title{
Urbanisation in West Bengal: An Analysis of Recent Processes
}

Biswajit Ghosh $^{+*}$ and Namita Chakma'

\section{Abstract}

The present work intends to study the recent processes of urbanisation of West Bengal by measuring some selected indices: like level of urbanisation, decadal growth of urban population, rate of urbanisation, pace of urbanisation and urban growth, contribution of growth in urban population to total growth and rural-urban displacement. It is a meso-level study, and 19 districts of the state have been selected as units of study. Using Principal Component Analysis (PCA), the research has identified three principal factors that determine the processes of urbanisation in the state: rural-urban displacement, decadal growth rate and rate of urbanisation. All these three factors responded positively in both primary and secondary loadings.

Key words: urbanisation, indices of urbanisation, process of urbanisation, principal factors.

* Corresponding Author

${ }^{\dagger}$ Assistant Teacher, Khorad Amena High School, Satgachhia, Barddhaman, India; Email: bswjtghsh40@gmail.com

' Assistant Professor, Department of Geography, The University of Burdwan, Barddhaman; India;

Email: namitachakma@gmail.com

(C)2014 Ghosh and Chakma. This is an Open Access article distributed under the terms of the Creative Commons Attribution License (http://creativecommons.org/licenses/by/2.0), which permits unrestricted use, distribution, and reproduction in any medium, provided the original work is properly cited. 


\section{Introduction}

Examining the process of urbanisation in different states of India remains a continuing concern among many scholars (Dasgupta, 1987; Giri, 1998; Konar, 2009; Sivaramakrishnan et al., 2005; Sita and Phadke, 1985; Samanta, 2012). In the said context, the recent processes of urbanisation in West Bengal are at the heart of understanding of this research. This is a meso-level study, where the 19 districts of West Bengal (except Alipurduar) have been selected. Using the Principal Component Analysis (henceforth PCA), an attempt has been made to determine the three principal factors of the processes of urbanisation in the state: rural-urban displacement, decadal growth rate and rate of urbanisation. It also aims to probe the pace of urbanisation using an Eldridge index. The research begins with the definition of urban areas as outlined by the Census of India. It then goes on to show the gap between urbanisation of India and West Bengal. Following this, the research discusses the methods deployed and then examines the process of urbanisation in West Bengal.

Census of India 2011, defines urban areas as: (a) all places with a municipality, corporation, cantonment board or notified town area committee, etc.; and (b) all other places with a minimum population of 5,000 , at least 75 per cent of the adult male main working population engaged in non-agricultural pursuits; and a density of population of at least 400 persons per sq. $\mathrm{km}$. The first category of urban units is known as statutory towns. These towns are notified under law by the concerned state/UT government and have local bodies like municipal corporations, municipalities, municipal committees, etc. whereas other towns are defined as census towns.
The Indian nation as a whole (including the state of West Bengal) has experienced gradual increase of urbanisation since 1951 though the rate of urbanisation is still low. In 1951, the percentage of urbanisation in West Bengal was only 23.90 , which increases to 31.89 per cent in 2011. The gap between the levels of urbanisation in India and West Bengal has also decreased from 6.61 per cent in 1951 to 0.78 per cent in 2011 (see Table-1).

West Bengal was one of the most urbanised states in the country in the early part of the 20th Century and was mainly based on Kolkata city. Dasgupta (1987) stated that urbanisation pattern was eventually evolved by the policy of the Britishers. That is, during British period, the tea gardens in Assam and plantation in Africa were the destination of labours from Bihar, Uttar Pradesh and Orissa. And in pre- and postIndependence period, huge influx of refugees from eastern part of Bengal resulted in concentration of huge number of people in and around Calcutta (now Kolkata) and in Asansol (Giri, 1988). However, the scenario has changed in the 21st century with the development of new census towns and the district-level spatial pattern of urbanisation. Pattern of urbanisation in the state is now independent of the metropolis and existing urban-industrial region (Samanta, 2012). Census data reveals that in West Bengal, census towns have jumped from 48 in 1971 to 780 in 2011, whereas the number of statutory towns remains 127 . As per the Census of India, 2011, West Bengal is the 4th most populous state $(91,276,115$ persons) of the country with a population density of 1,029 persons per sq. $\mathrm{km}$. Current urbanisation rate of West Bengal is 31.87 per cent (slightly above the national average). Here, an attempt has been made to analyse the recent processes of urbanisation in West Bengal (please refer to Fig. 1). 


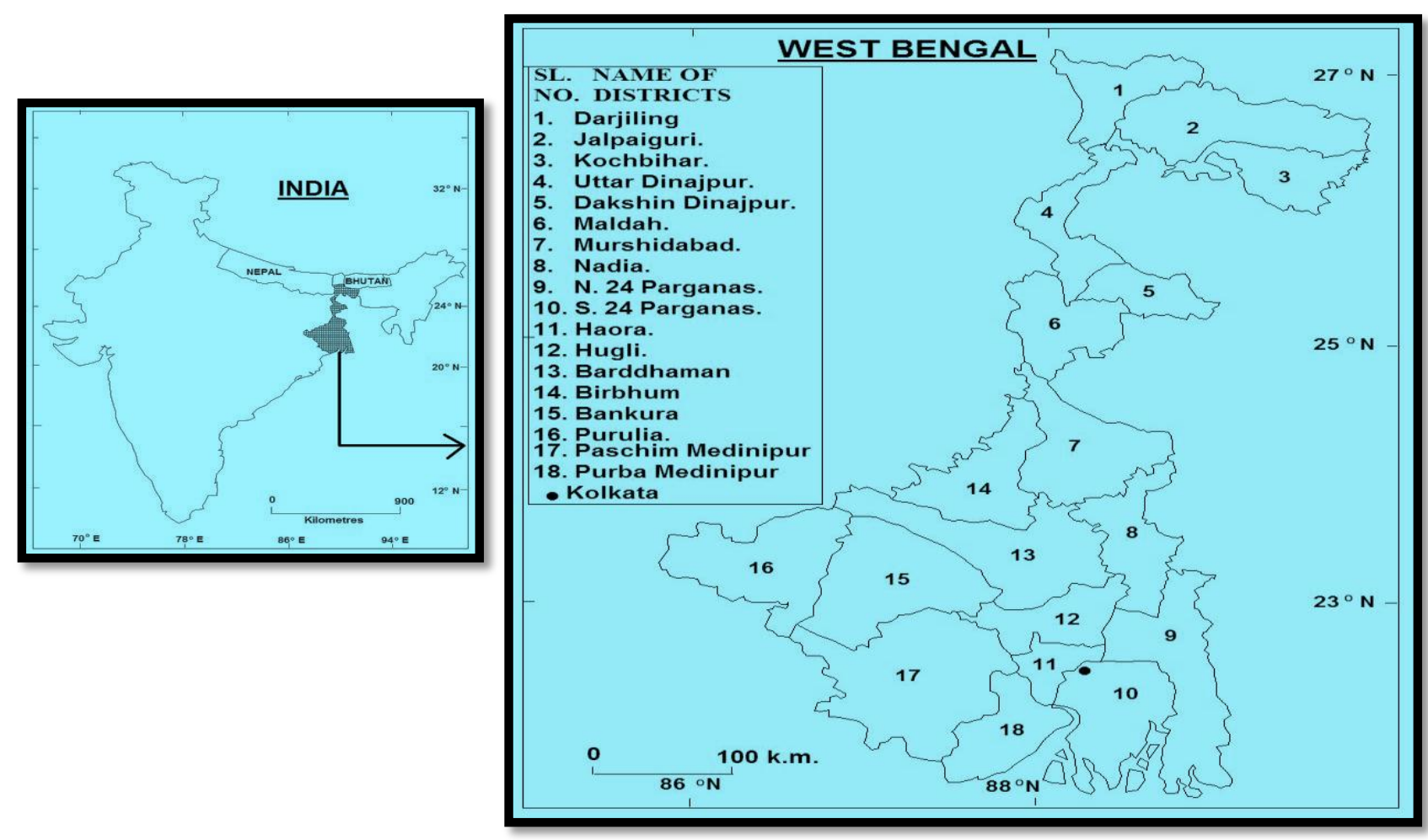

Fig. 1: Recent Processes of Urbanisation in West Bengal

(Source: Prepared by authors)

\section{Table 1: Urban Population in India and West Bengal, 1951-2011}

\begin{tabular}{llll} 
Year & $\begin{array}{l}\text { Percentage of urban } \\
\text { population } \\
\text { in India }\end{array}$ & $\begin{array}{l}\text { Percentage of urban } \\
\text { population in West Bengal }\end{array}$ & Difference \\
\hline 1951 & 17.29 & 23.90 & 6.61 \\
\hline 1961 & 17.97 & 24.40 & 6.43 \\
\hline 1971 & 19.91 & 24.70 & 4.79 \\
\hline 1981 & 23.34 & 26.50 & 3.16 \\
\hline 1991 & 25.72 & 27.48 & 1.76 \\
\hline 2001 & 27.78 & 28.03 & 0.25 \\
\hline 2011 & 31.16 & 31.89 & 0.78
\end{tabular}

Sources: Census of India 1981 and 1991, Paper-2, Rural-Urban Distribution; ILGUS, 2002; Census 2001 and 2011

\section{Materials and Methods}

The study is based on secondary sources of information. Data sources are primarily Census of India 1981, 1991, 2001 and 2011. As mentioned above, it is a meso-level study.
Using PCA, the research aims to examine the trends and processes of urbanisation of 19 districts of West Bengal without the incorporation of the Alipurduar district. PCA is a statistical technique to find out the dominant 
variables from a set of variables operating in a system and it helps in decision-making process of spatial planning. The process of urbanisation has been analysed on the basis of selected urban indices-level of urbanisation, decadal growth of urban population and the rate of urbanisation (Sivaramakrishnan et al., 2005please see below for the definition of these phrases). In addition, the Eldridge index (Vaidyanathan, 1981) is also used to investigate the pace of urbanisation. Eldridge index indicates change in proportion of urban population as a ratio to the maximum possible percent change. [Please refer to Sita and Phadke (1985), who used this index to analyse the pace of urban growth and rural-urban displacement in their study.]

(a) Level of urbanisation: It expresses the percentage of urban population with respect to the total population for a particular time. Thus,

Level of Urbanisation = (Urban Population: Total Population) $\times 100$

(b) Decadal growth of urban population, which indicates the degree of urbanisation with respect to time. Thus,

Decadal growth of urban population (20012011) $=\{$ Urban Population (2011) - Urban Population (2001) $\div \div$ Urban Population (2001) X 100

(c) Rate of Urbanisation indicates decadal change in percentage of urban population. Thus,

Rate of Urbanisation (2001-2011) $=$ (Per cent of Urban Population in 2011- Per cent of Urban Population in 2001) $\div$ Per cent of Urban Population in $2001 \times 100$

(d) As stated earlier, the Eldridge index (Vaidyanathan, 1981) is used to measure the pace of urbanisation. However, certain difficulties arose in areas like Kolkata with 100 per cent urban population. Thus, Pace of Urbanisation $(2001-2011)=($ Per cent of Urban Population in 2011 - Per cent of Urban Population in 2001) $\div 100$ - Per cent of Urban Population in $2001 \times 100$ (e) Pace of urban growth takes into consideration absolute growth in urban population in relation to maximum possible growth during the decade. Thus, pace of Urban Growth $(2001-2011)=$ (Urban Population in 2011 - Urban Population in 2001) $\div$ (Total Population in 2011 - Urban Population in 2001) X 100

(f) Contribution of growth in urban population to total growth of population is an important measure for analysing process of urbanisation as well. Thus, contribution of Growth in Urban Population to Total Growth (2001-2011) = (Urban Population in 2011-Urban Population in 2001) $\div$ (Total Population in 2011 - Total Population in 2001) X 100

(g) Lastly, a measure of rural-urban displacement has also been considered. Thus, rural-urban displacement (2001-2011) $=\{$ Urban Population in 2011 - (Total Population in 2011 $X$ Per cent of Urban Population in 2001)\} $\div$ Urban Population in 2011 X 100

Standard score has been calculated to generate the composite score value. In statistics, a standard score indicates by how many standard deviations an observation is above or below the mean. The Standard score $(z)$ of a raw score ' $x$ ' is:

$z=(x-\mu) \div \sigma$,

where, $\mu$ is the mean; $\sigma$ is the standard deviation. And as mentioned above, to probe the most dominant indices and to estimate the inter districts variation, PCA technique has been used with the help of XLSTAT (2006) software. However, before embarking on the results and discussion, it is also essential to define the following terms.

Q-MODE ANALYSIS: A geographical system that consists of space or spaces and variables. Different variables perform in spaces differently depending on existing circumstances. $\mathrm{Q}$ - mode analysis is that part of PCA, which analyses the performance of the variables in different stages of analysis.

R-MODE ANALYSIS: It is that part of PCA, which analyses the performance of the spaces 
of a geographical system resulting from the interaction of the variables.

EIGEN VALUE: The values of the coefficient vector of the components are called Eigen vector and variance of component is equal to Eigen value of the Eigen vector. The component, which corresponds to the highest, and the second highest Eigen value are known as first principal component and second principal component respectively. In this way rest, Principal Components are selected.

FACTOR SCORE: In different analysis of PCA the components (space or variable) response with respect to their relative importance in all stages. These responses are recorded numerically which are known as factor score. Sum of these scores in all stages is equal to one for each component.

\section{Results and Discussion}

\section{Spatial Distribution of Urban Population, 2011}

In the state, urban population distribution pattern varied widely across the districts. The districts of Murshidabad, Barddhaman, Nadia, Hugli, Haora, North 24 Parganas and South 24 Parganas are experiencing a very high density of urban population. Comparatively high level of economic development in those districts create a centripetal force in urban areas which attracts people in those urban areas from other parts of district for employment On the other hand, urban development in the districts of Birbhum, Purulia and Bankura bears low density. The low density distribution of urban population is also found in Jalpaiguri, Koch Bihar, Uttar Dinajpur, Dakshin Dinajpur and Maldah districts (please refer to Fig. 2) due to comparatively lower level of economic development of urban areas in those districts.

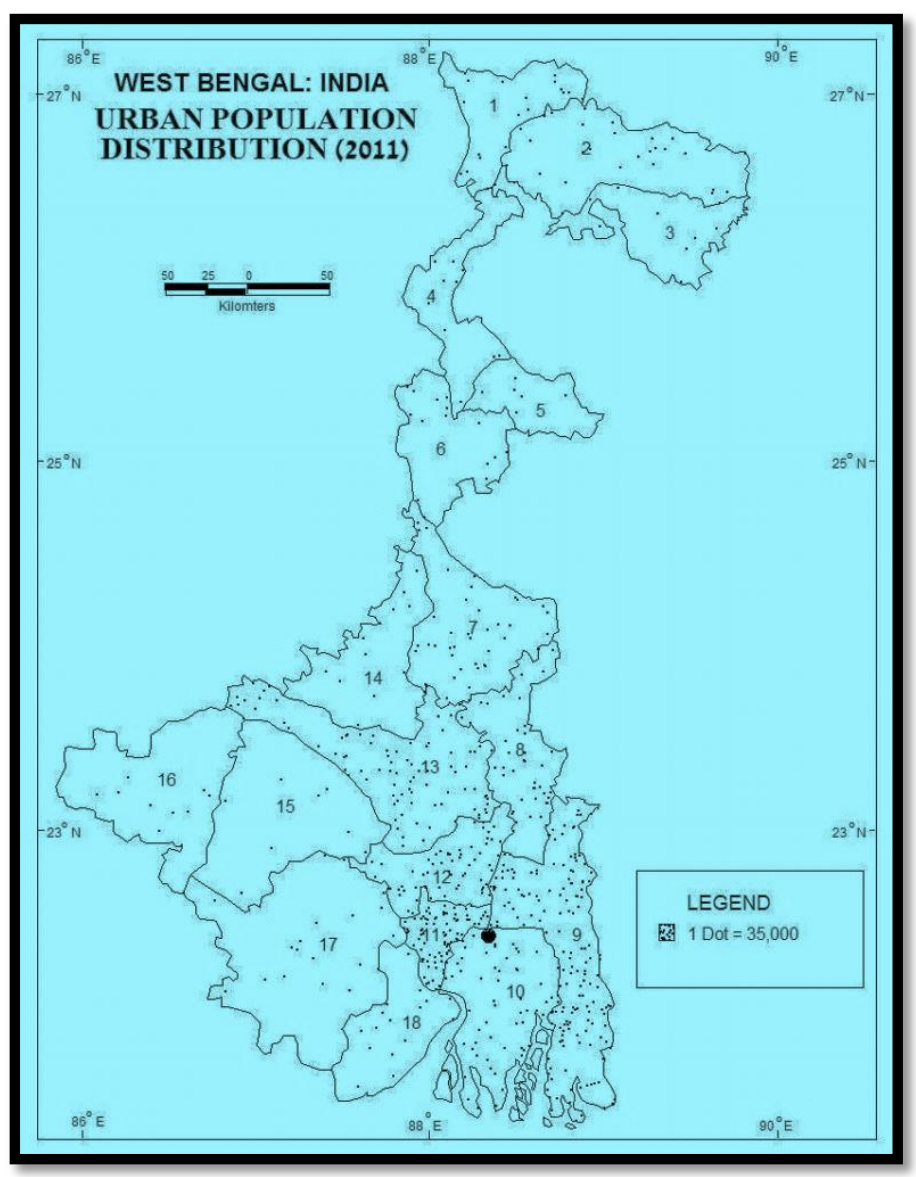

Fig. 2

(Source: Prepared based on author's calculation) 


\section{Level of Urbanisation in 2011}

The pattern of level of urbanisation in West Bengal perfectly coincides with the pattern of urban population distribution except for Darjiling. In 13 districts of West Bengal, the level of urbanisation is less than the national average. Only five districts like Darjiling, Barddhaman, Hugli, Haora and North 24 Parganas are experiencing a high level of urbanisation than the national average (please refer to Fig. 3).

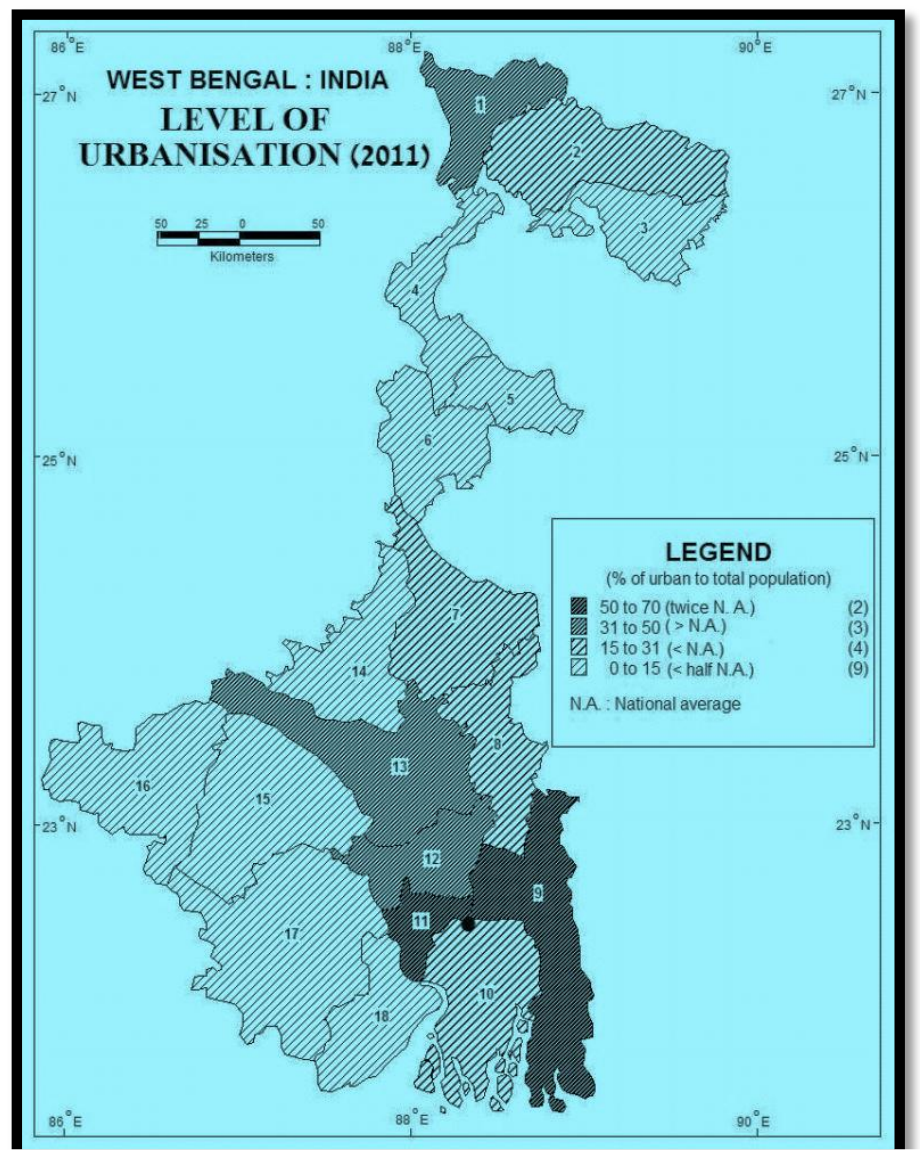

Fig. 3

(Source: Prepared based on author's calculation)

\section{Decadal Growth Rate in 2001-2011}

In four districts of the state, namely Maldah, Murshidabad, Paschim Medinipur and South 24 Parganas, the decadal growth rate of urban populations has doubled at a rate, which is thrice the national average, while in Jalpaiguri and Birbhum districts, it is twice the national average. Darjiling, Purulia and Haora districts have also shown growth rates more than the national average. Hugli and Barddhaman districts have recorded very low rate of decadal growth in spite of higher concentration of urban population there. Interestingly, the growth rate in Kolkata has been found negative (please refer to Fig. 4) due to poor quality of urban services resulting from higher concentration of people in a constant area or space.

\section{Rate of Urbanisation in 2001-2011}

West Bengal has recorded a positive rate of urbanisation during 2001-2011. It indicates increasing number of urban areas in all districts. Interestingly, inter-district variation exists as well. The rate of urbanisation is lower than the national average in Uttar Dinajpur, Dakshin Dinajpur, Barddhaman and Purba Medinipur districts due to lower growth in percentage of urban population in 2001-2011 than in 19912001, but it is more than five times high than the national average in Maldah and South 24 Parganas districts due to higher growth in percentage of urban population in 2001-2011 than in 1991-2001 (please refer to Fig. 5). 


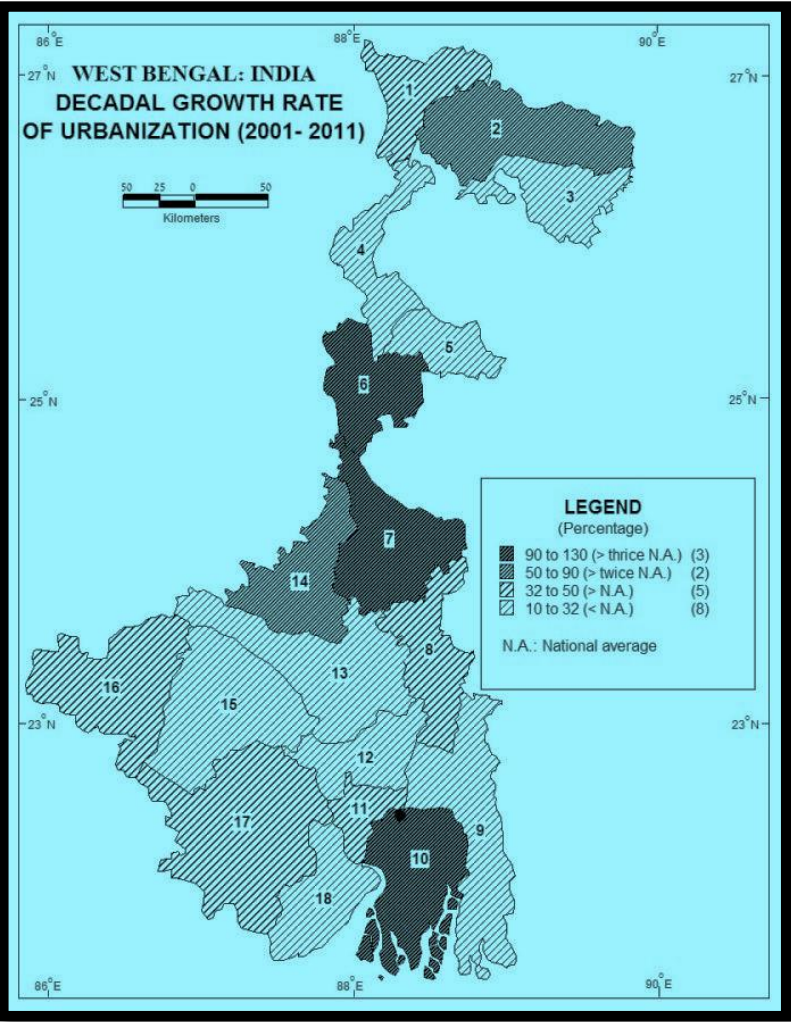

Fig. 4

(Source: Prepared based on author's calculation)

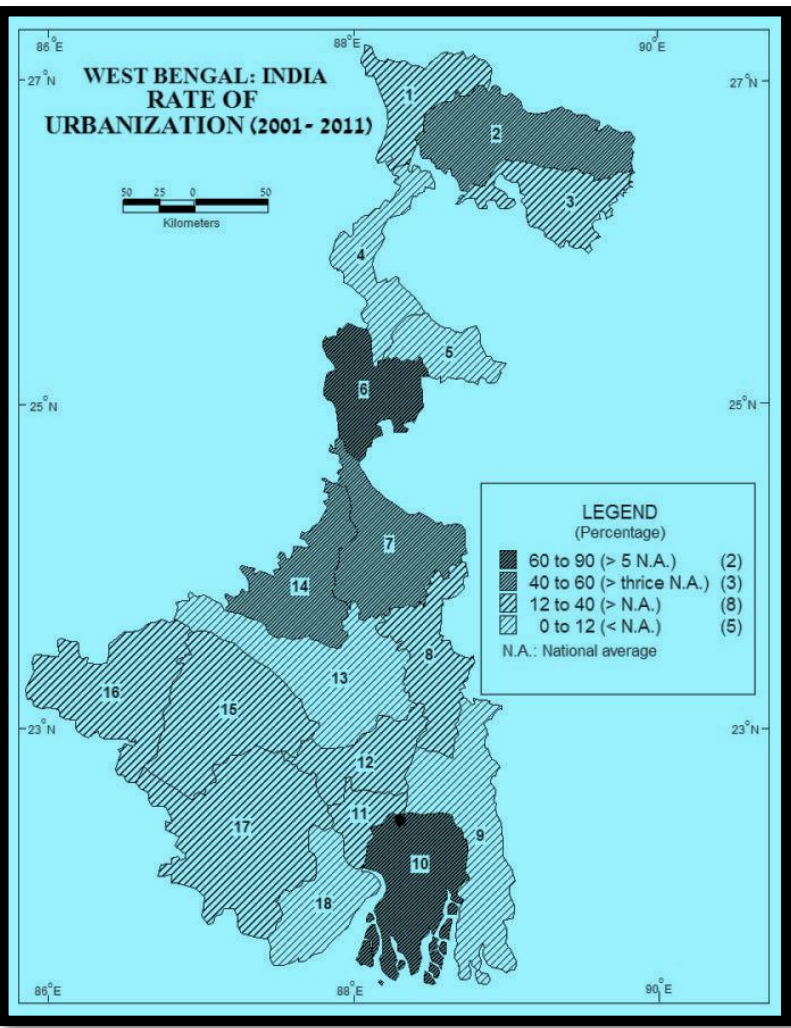

Fig. 5

(Source: Prepared based on author's calculation) 


\section{Pace of Urbanisation in 2001-2011}

Nine districts of West Bengal are urbanising at a pace less than the national average. Due to proximity to the Kolkata Metropolitan area and industrial development, Haora is urbanising at a pace more than five times the national average.
All other districts also show positive pace of urbanisation during the period as all districts are experiencing a positive growth in urban population in every decade with respect to the previous decade (please refer to Fig. 6).

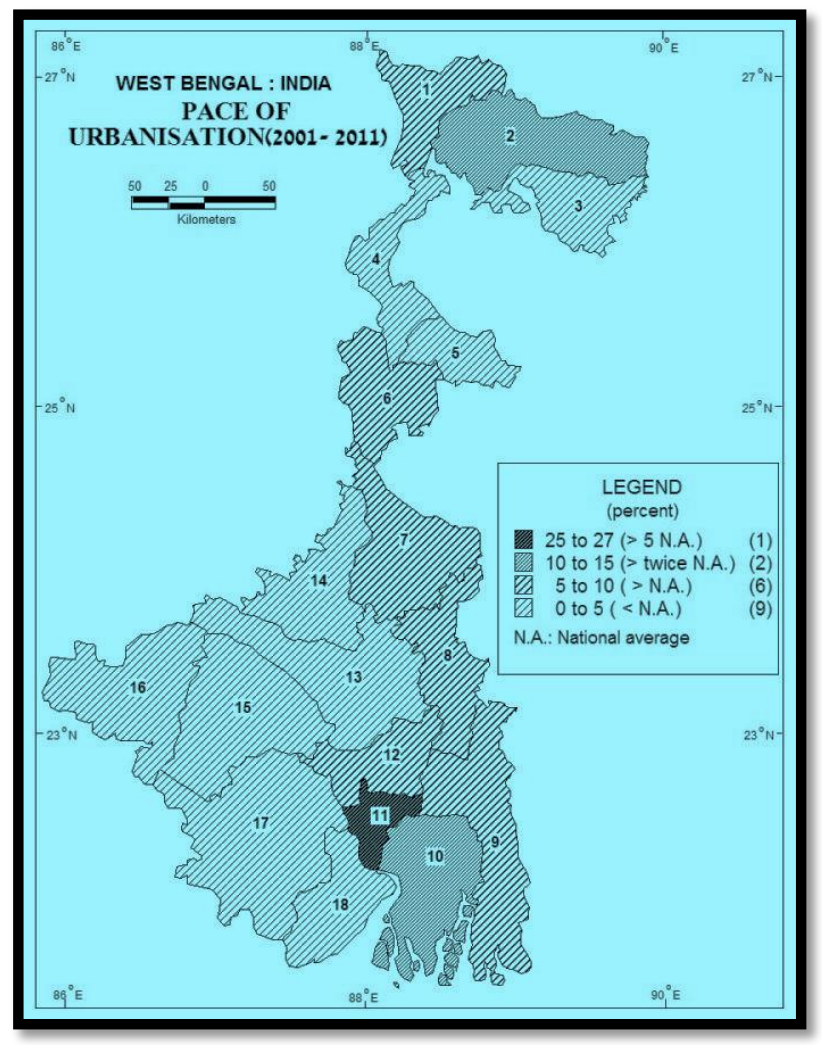

Fig. 6

(Source: Prepared based on author's calculation)

\section{Pace of Urban Growth in 2001-2011}

All districts have shown positive pace of urban growth during the period though there exists inter-district variation. Kolkata has recorded an absolute growth. Nine districts have recorded the growth less than the national average as their change in urban population with respect to the change in total population is lower than that in national level and other districts have shown the growth more than the national average indicating a higher change in urban population with respect to the change in total population than that in national level (please refer to Fig. 7).

\section{Contribution of Growth in Urban Population to Total Growth in 2001-2011}

Only seven districts namely Koch Bihar, Uttar Dinajpur, Dakshin Dinajpur, Maldah, Birbhum, Purba and Paschim Medinipur have contributed less than 50 per cent. This is largely because these districts are dominated by rural population. Other districts are contributing more urban population growth during the period because these districts have comparatively higher percentage of urban population. So growth of urban population has a positive contribution to the total population system. Haora is experiencing a very high rate of increase. It is more than thrice the national average (please see Fig. 8). 


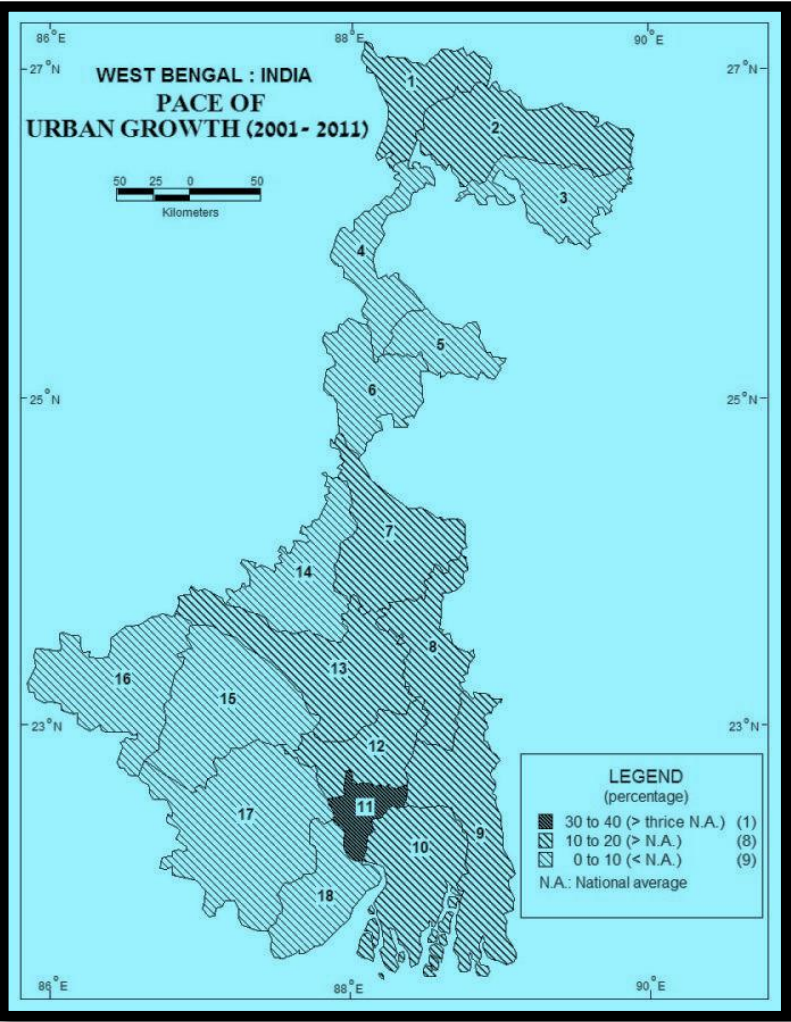

Fig. 7

(Source: Prepared based on author's calculation)

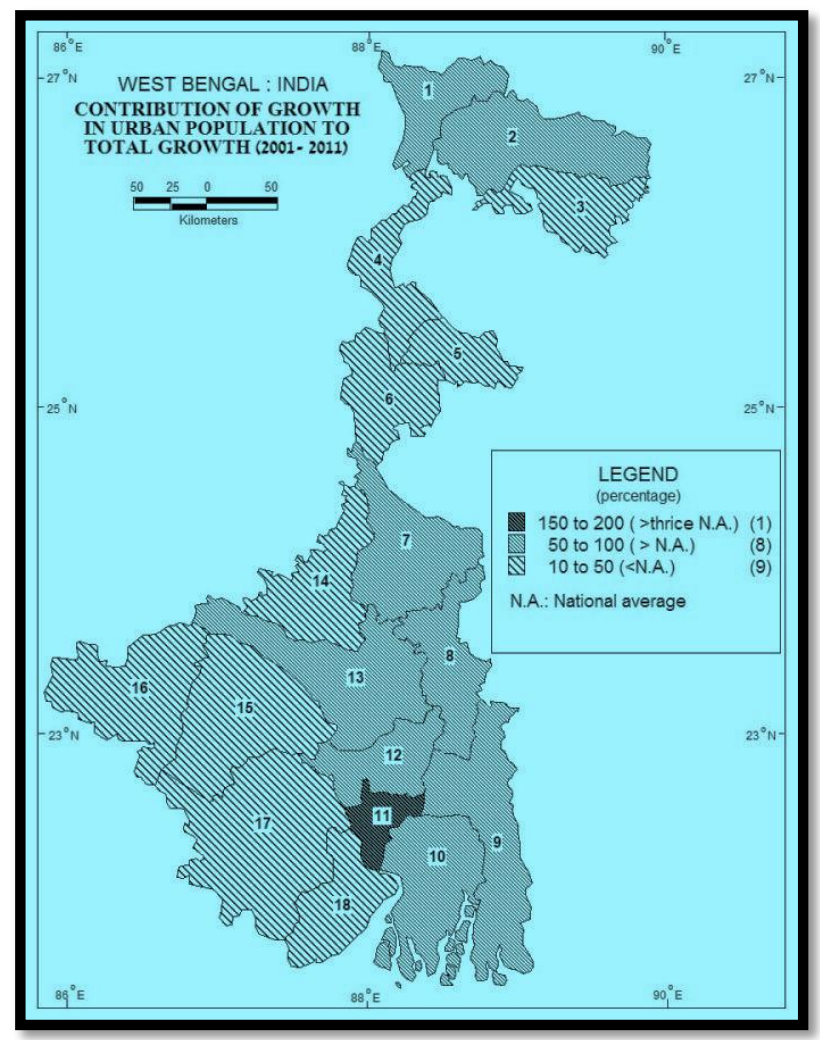

Fig. 8

(Source: Prepared based on author's calculation) 


\section{Rural-Urban Displacement in 2001-2011}

Inter-district variation has also been found during the period. Rural-Urban displacement rate is less than the national average in Uttar Dinajpur, Dakshin Dinajpur, Barddhaman, North 24 Parganas and Purba Medinipur districts. Other districts have shown the rate more than the national average. Among them Maldah has recorded the maximum percentage where 47 per cent of urban people have been displaced from rural areas during the period. Jalpaiguri, Murshidabad, Birbhum and South 24 Parganas districts have also influenced their surrounding rural areas with a value more than thrice than the national average because urban areas in those districts are playing a dominating role within their sphere of influence which results in migration of rural people to urban centres for job (please see Fig. 9).

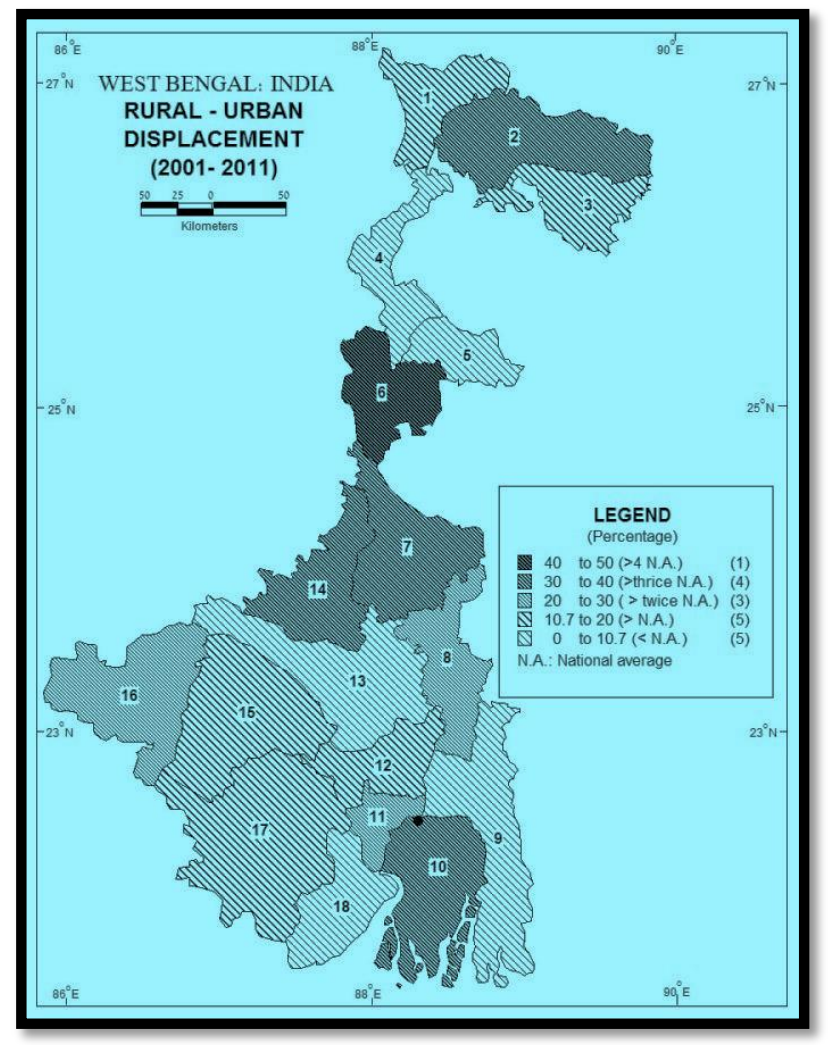

Fig. 9

(Source: Prepared based on author's calculation)

\section{Principal Factors of Urbanisation in West Bengal, 2001-2011}

To find out the dominant factors among the aforesaid indices, PCA technique has been applied. [Table-2 (i, ii, iii, iv); Fig. 10]. Results show that the selected variables have extracted 97.15 per cent of the variance. At the first stage of analysis (56.56 per cent) three measures namely pace of urbanisation, pace of urban growth and contribution of growth in urban to total growth are able to extract 36.85 per cent of the variance with a strong positive linkage with other measures like level of urbanisation, rate of urbanisation, decadal growth rate of urban population and rural-urban displacement. However, in secondary loading these measures are showing a negative influence. Other three factors like rate of urbanisation, decadal growth rate of urban population and rural-urban displacement have become dominant in secondary loading. Ruralurban displacement, decadal growth rate and rate of urbanisation have responded positively in both primary and secondary loading. Therefore, these three factors are principal components for urbanisation process in West Bengal. Konar (2009) has stated that a very important factor causing high growth rate of 
urbanisation in the state of West Bengal lies in areas.

massive migration from rural areas to urban

\section{Table-2: PCA; (i) Correlation Matrix}

\begin{tabular}{|c|c|c|c|c|c|c|c|}
\hline$\frac{\frac{y}{0}}{\frac{0}{\frac{\pi}{2}}}$ & 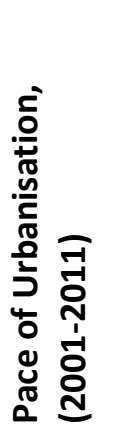 & 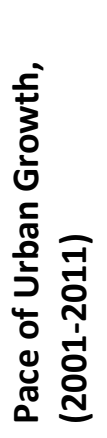 & 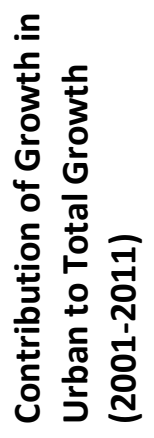 & 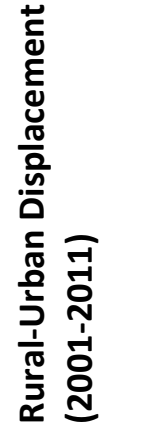 & 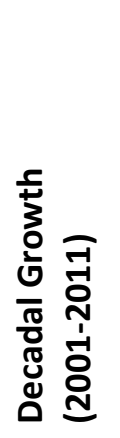 & 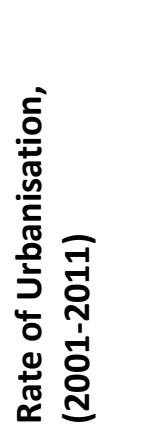 & 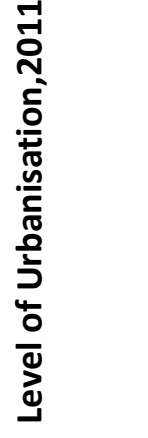 \\
\hline $\begin{array}{l}\text { Pace of } \\
\text { Urbanisation } \\
(2001-2011)\end{array}$ & 1 & 0.957 & 0.941 & 0.394 & 0.294 & 0.339 & 0.752 \\
\hline $\begin{array}{c}\text { Pace of Urban } \\
\text { Growth (2001- } \\
\text { 2011) }\end{array}$ & 0.957 & 1 & 0.960 & 0.205 & 0.123 & 0.163 & 0.902 \\
\hline $\begin{array}{l}\text { Contribution of } \\
\text { Growth in Urban } \\
\text { to Total Growth } \\
(2001-2011)\end{array}$ & 0.941 & 0.960 & 1 & 0.244 & 0.121 & 0.183 & 0.883 \\
\hline $\begin{array}{c}\text { Rural-Urban } \\
\text { Displacement } \\
\text { (2001-2011) }\end{array}$ & 0.394 & 0.205 & 0.244 & 1 & 0.964 & 0.986 & -0.116 \\
\hline $\begin{array}{l}\text { Decadal Growth } \\
\text { (2001-2011) }\end{array}$ & 0.294 & 0.123 & 0.121 & 0.964 & 1 & 0.992 & -0.188 \\
\hline $\begin{array}{l}\text { Rate of } \\
\text { Urbanisation } \\
\text { (2001-2011) }\end{array}$ & 0.339 & 0.163 & 0.183 & 0.986 & 0.992 & 1 & -0.146 \\
\hline $\begin{array}{c}\text { Level of } \\
\text { Urbanisation, } 2011\end{array}$ & 0.752 & 0.902 & 0.883 & -0.116 & -0.188 & -0.146 & 1 \\
\hline
\end{tabular}

\section{Source: Computed by the authors}

\section{Q-MODE ANALYSIS}

\section{Table-2 (ii): Calculation of Eigen values}

\begin{tabular}{ccccccccc} 
& F1 & F2 & F3 & F4 & F5 & F6 & F7 \\
\hline Eigen value & 3.959 & 2.842 & 0.125 & 0.059 & 0.013 & 0.002 & 0.001 \\
\hline Variability (Percent) & 56.558 & 40.596 & 1.781 & 0.839 & 0.187 & 0.025 & 0.014 \\
\hline Cumulative Percent & 56.558 & 97.154 & 98.935 & 99.774 & 99.961 & 99.986 & 100.000
\end{tabular}

\section{Source: Computed by the authors}




\begin{tabular}{llllllll}
\multicolumn{7}{c}{ Table-2 (iii): Calculation of Factor score } \\
& F1 & F2 & F3 & F4 & F5 & F6 & F7 \\
\hline Pace of Urbanisation (2001-2011) & 0.955 & -0.194 & -0.217 & -0.055 & -0.004 & 0.011 & -0.016 \\
\hline Pace of Urban Growth (2001-2011) & 0.913 & -0.391 & -0.017 & -0.111 & 0.034 & -0.008 & 0.019 \\
\hline $\begin{array}{l}\text { Contribution of Growth in Urban to Total } \\
\text { Growth (2001-2011) }\end{array}$ & & & & & & & \\
\hline Rural-Urban Displacement (2001-2011) & 0.914 & -0.369 & -0.028 & 0.158 & -0.054 & -0.009 & 0.006 \\
\hline Decadal Growth (2001-2011) & 0.579 & 0.806 & -0.016 & 0.098 & 0.077 & -0.010 & -0.004 \\
\hline Rate of Urbanisation (2001-2011) & 0.494 & 0.859 & 0.079 & -0.093 & -0.050 & -0.021 & -0.006 \\
\hline Level of Urbanisation, 2011 & 0.540 & 0.839 & 0.064 & 0.003 & -0.018 & 0.031 & 0.009 \\
\hline Source: Computed by the authors & 0.713 & -0.652 & 0.257 & -0.003 & 0.018 & 0.006 & -0.012 \\
\hline
\end{tabular}

\section{R-MODE ANALYSIS}

\section{Table-2 (iv): Calculation of Factor Score}

\begin{tabular}{llllllll} 
Districts/ Observation & $F 1$ & $F 2$ & $F 3$ & $F 4$ & $F 5$ & $F 6$ & $F 7$ \\
\hline Darjiling & 1.012 & -1.154 & 0.079 & 0.061 & 0.028 & -0.039 & -0.031 \\
\hline Jalpaiguri & 1.877 & 0.951 & -0.172 & 0.373 & -0.080 & -0.008 & 0.064 \\
\hline Koch Bihar & -2.160 & -0.091 & -0.233 & -0.047 & 0.046 & 0.023 & 0.005 \\
\hline Uttar Dinajpur & -2.732 & -0.839 & -0.106 & -0.404 & -0.265 & -0.084 & 0.019 \\
\hline Dakshin Dinajpur & -2.221 & -0.602 & -0.146 & 0.002 & -0.021 & 0.082 & -0.003 \\
\hline Maldah & 1.535 & 4.008 & 0.455 & -0.291 & -0.148 & 0.067 & 0.001 \\
\hline Murshidabad & 1.157 & 2.075 & 0.078 & -0.165 & 0.070 & -0.073 & -0.049 \\
\hline Nadia & 0.694 & -0.114 & -0.114 & 0.403 & -0.036 & -0.030 & 0.022 \\
\hline North24 Parganas & 0.818 & -2.669 & 0.960 & -0.213 & 0.139 & -0.009 & 0.060 \\
\hline South 24 Parganas & 2.180 & 1.777 & -0.052 & -0.019 & -0.028 & -0.004 & 0.004 \\
\hline Haora & 5.065 & -2.744 & -0.707 & -0.357 & 0.022 & 0.030 & -0.008 \\
\hline Hugli & 0.493 & -1.491 & 0.169 & 0.506 & -0.182 & 0.007 & -0.029 \\
\hline Barddhaman & -0.415 & -1.728 & 0.532 & 0.087 & -0.028 & 0.035 & -0.062 \\
\hline Birbhum & -0.099 & 1.905 & 0.015 & 0.104 & 0.163 & -0.006 & 0.005 \\
\hline Bankura & -2.255 & 0.020 & -0.289 & -0.022 & 0.073 & 0.042 & 0.019 \\
\hline Purulia & -1.181 & 0.650 & -0.126 & 0.056 & 0.148 & -0.032 & -0.012 \\
\hline Paschim Medinipur & -1.432 & 0.462 & -0.159 & 0.066 & 0.133 & -0.013 & -0.004 \\
\hline Purba Medinipur & -2.333 & -0.416 & -0.187 & -0.139 & -0.034 & 0.012 & -0.001 \\
\hline Source: Computed by the & & & & & & &
\end{tabular}

Source: Computed by the authors 


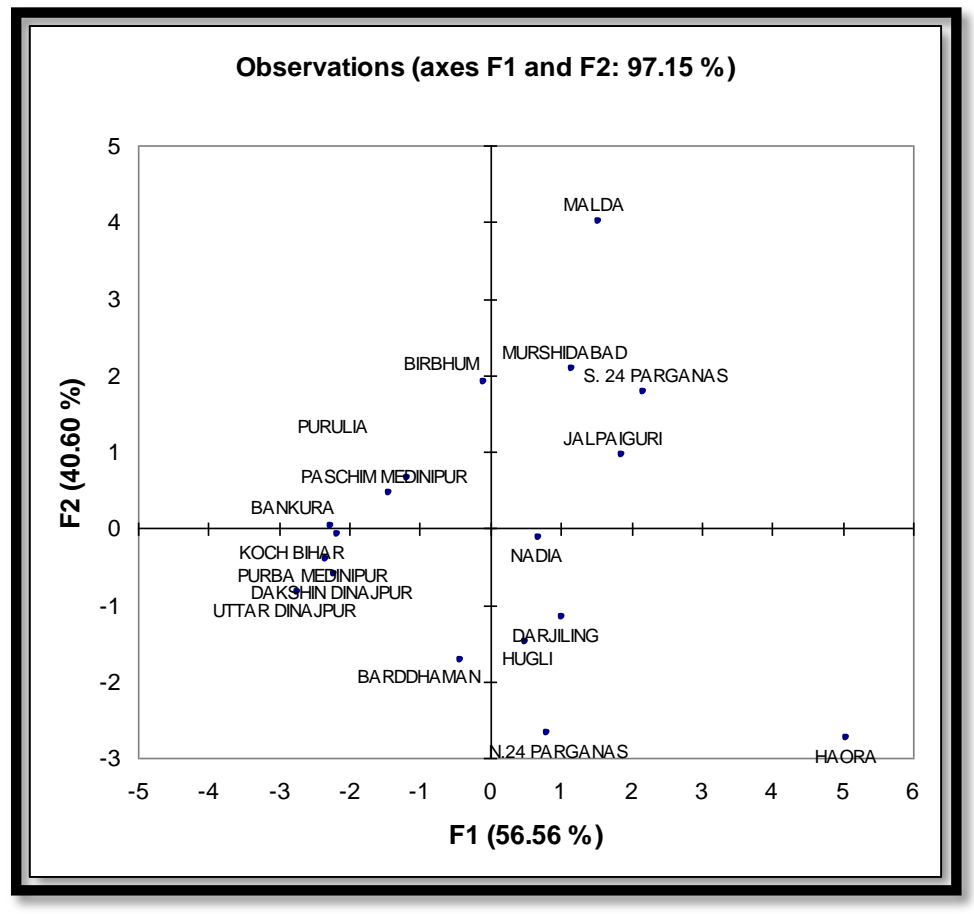

Fig. 10

A very high loading of Haora at the primary level indicates a very developed condition in the perspective of urbanisation but in secondary loading, Haora has responded negatively due to its low value of decadal growth rate of urban population, rate of urbanisation and rural-urban displacement measures. Maldah, Murshidabad, South 24 Parganas and Jalpaiguri have shown positive loading in both primary and secondary stages, so these are in more advanced stages of urbanisation. Nadia, Darjiling, Hugli, North 24 Parganas and Haora are in relatively less advanced stages as they have positive primary loading and negative secondary loading whereas, other districts are in less urbanised stages.

\section{Conclusion}

West Bengal has experienced a high level of urbanisation during 2001-2011 though high inter-district disparity exists in urban population distribution. In the state, urban process is strongly dominated by the indices of decadal growth rate, rate of urbanisation and rural-urban displacement factors. The growth of population as a result of in-migration and natural increase is indeed a matter of great concern. A proper planning should come from the central as well as state government to enhance necessary infrastructure so that inequality among districts may be eliminated effectively.

\section{References}

Census of India 1981. Provisional Population Totals, Paper 2: Rural-Urban Distribution, Office of the Registrar General and Census Commission, India, New Delhi

Census of India 1991. Provisional Population Totals, Paper-2, Rural-Urban Distribution, Office of the Registrar General and Census Commission, India, New Delhi

Census of India 2001. Provisional Population Totals, Paper 1, West Bengal, Office of the Registrar General and Census Commission, India, New Delhi

Census of India 2011. Provisional Tables, Paper 2, Office of the Registrar General and Census Commission, India, New Delhi

Dasgupta, B. 1987. Urbanisation and Rural Change in West Bengal, Economic and Political Weekly, Vol. 22, No. 7, Mumbai, pp. 276-287 
Giri, P. 1998. Urbanisation in West Bengal, 1951-1991, Economic and Political Weekly, Vol.33, No.47/48, Mumbai, pp. 3033-3038

ILGUS 2002. Urban West Bengal, Institute of Local Government and Urban Studies, Calcutta

Konar, D.N. 2009. Nature of Urbanisation in West Bengal in the Post-Independence Period, Retrieved on June 13, 2013, from www.mimts.org

Samanta, G. 2012. In Between Rural and Urban: Challenges for Governance of Non-recognized Urban Territories in West Bengal, in Jana, N.C. et al. (edited), West Bengal, Geo-Spatial Issues, Department of Geography, The University of Burdwan

Sita, K. and Phadke V.S. 1985. Urbanisation in Maharashtra, 1971-81, in Prasad, N. Banerjee, S and Dutt, G.K (edited), Modern Geographical Concepts, Department of Geography, The University of Burdwan, pp. 265

Sivaramakrishnan, K.C., Kundu, A and Singh, B.N. 2005. Handbook of Urbanisation in IndiaAn Analysis of Trends and Processes, Oxford University Press, pp. 177

Vaidyanathan, K.E. 1981. Rural-Urban Distribution of Population in West Asia, Population Geography, 3 (1\&2), pp. 96-113 